\title{
Beyond vegetative propagation of indigenous fruit trees: case of Dacryodes edulis (G. Don) H. J. Lam and Allanblackia floribunda Oliv.
}

\author{
Ebenezar K. Asaah (1,2), Zac Tchoundjeu (1), \\ Patrick Van Damme (2)
}

(I) World Agroforestry Centre (ICRAF), Yaounde, Cameroon

(2) Department of Plant Production, Ghent University, Belgium

\begin{abstract}
Indigenous fruits/nuts of Africa's humid tropics are increasingly being recognized for their contribution to food security, health (nutrition/medicine), income generation, employment and environmental benefits. However, cultivation of the trees yielding these fruits/nuts is constrained by lack of improved planting materials that are true-to-type and have a short enough juvenile phase to fruit production. In addition, information on both above and belowground growth attributes of these species is scarce. This paper presents an overview of the results of a doctoral research focused on two African indigenous fruit tree species, i.e. Dacryodes edulis (G. Don) H. J. Lam (Burseraceae) and Allanblackia floribunda Oliv. (Clusiaceae), which are currently under domestication. For D. edulis, the objective was to assess and compare the structural and fine rooting systems together with the above ground growth attributes of fruiting trees propagated either sexually or vegetatively. The research aim for A. floribunda was to shorten the long juvenile phase before first fruiting through grafting techniques. In summary, the results from the studies on $D$. edulis suggest that vegetative propagation of the species, reduces the long juvenile phase to fruiting and maintains trueness in the transfer of desirable traits over generations, it also results in trees that are apparently less competitive for below ground resources, have more stable root system, and are bigger in stature and higher in carbon sinks compared to trees of seed origin. In parallel, A. floribunda was shown to be amenable to grafting both under nursery and field (in situ) conditions. Furthermore, a grafted A. floribunda tree transplanted in the field in 2007 , flowered and carried a single fruit to maturity after 4 years, thereby reducing the long juvenile period to first fruit production from about 10-12 years reported in literature to less than 5 years. The findings of this doctoral research are therefore pertinent to efforts towards indigenous fruit/nut tree domestication. However, research should be confirmed as it can be considered a pilot study, one that aims to obtain insights into the effect of vegetative propagation methods on above and below ground growth and development of improved planting materials of $D$. edulis and $A$. floribunda under domestication.
\end{abstract}

Key words: carbon sequestration, cuttings, diversification, domestication, vegetative propagation 


\section{Introduction}

Dacryodes edulis (G. Don) H. J. Lam (Burseraceae) and Allanblackia floribunda Oliv. (Clusiaceae), are two African indigenous fruit tree species which are currently under domestication because of their high food, income and environmental security values. According to Simon and Leakey (2004), domestication of agroforestry trees encompasses both the socio-economic and biophysical processes involved in the identification and characterization of germplasm resources; the capture, selection and management of genetic resources; and the regeneration and sustainable cultivation of the species in managed ecosystems. The importance of domesticating and integrating these high-value fruit trees in agricultural landscapes by farmers is increasingly being recognized in Africa's humid tropics. However, in an agroforestry context, there has been scant research into the above and below ground growth attributes of intercropped trees that determine whether the association will be complementary or competitive. Similarly, indigenous fruit/nut species propagation by grafting has been little studied. The focus of the present research on D. edulis, was to assess and compare the structural and fine rooting systems together with the above ground growth attributes of trees propagated sexually and vegetatively, while on A. floribunda, the thrust was on how to reduce the long juvenile phase of about IO-I2 years before first fruiting through grafting techniques.

\section{Rationale}

Below ground and above ground growth attributes of vegetative/clonal propagules seem to be different from those of plants grown from seeds. These growth attributes have not been subject to extensive study and consequently are not well understood. Below ground tree growth attributes (rooting pattern and distribution) are very important not only for water and nutrient uptake, but also for support and anchorage. Knowledge of rooting/root distribution and the development of root systems is essential to an understanding of the ecological niche of tree species which in turn makes it possible to optimize the trees' productivity in various agroforestry systems (Huxley, 1983; Von Maydell, 1987; Toky and Khosla, 1989). Akinnifesi et al. (2004) and Vogt and Persson (199r), classified tree root systems into 2 main components based on root diameter: (i) a main structural roots component (diameter $>2 \mathrm{~mm}$ ) for support and anchorage of the plant; and (ii) a fine roots component (diameter $\leq 2 \mathrm{~mm}$ ), which consist of long exploratory, branching roots with root hairs for water and nutrient uptake.

The spatial and temporal distribution of roots in multispecies agro-ecosystems is known to vary according to species, tree husbandry and edaphic site factors (Akinnifesi et al., 1995; Schroth 1995; 1998; van Noordwijk and Purnomosidhi, 1995). According to van Noordwijk and Purnomosidhi (1995), desirable root architecture requirement differs for sequential and simultaneous agroforestry systems.

Fine root length, for example, is a relevant estimator of the rooting system's capacity for water and nutrient uptake (Akinnifesi et al., 2004; Anderson and Ingram, 1993). According to Schroth (I995) and van Noordwijk and Purnomosidhi (1995), data on root abundance as a function of soil depth are needed to get an idea about the ability to com- 
pete for below ground water and nutrients. The decrease in fine root volume of shea tree or karité (Vitellaria paradoxa) and néré (Parkia biglobosa) trees in the $0-20 \mathrm{~cm}$ soil stratum following root pruning during the cropping season has been reported to reduce tree $\mathrm{x}$ crop competition for below ground resources resulting in yield increase of (mostly annual) companion crops (Bayala et al., 2004). Several authors have examined the distribution of structural primary roots (Akinnifesi et al., 1999; Asaah et al., 2010; Coutts 1983; Toky and Khosla, 1989). Other research efforts have described and compared the fine root distribution of 8 tree species in India (Chaturvedi and Das, 2003); 13 multipurpose trees in Nigeria (Akinnifesi et al., 1999); Grevillea robusta and Gliricidia sepium in Kenya (Odhiambo et al., 2001); and Senna siamea in three regions of Togo (Vanlauwe et al., 2002). Until now, little or no research work has been done on indigenous trees under domestication in Africa with the aim of understanding the rooting system distribution of transplanted trees of vegetative and seed origins, respectively.

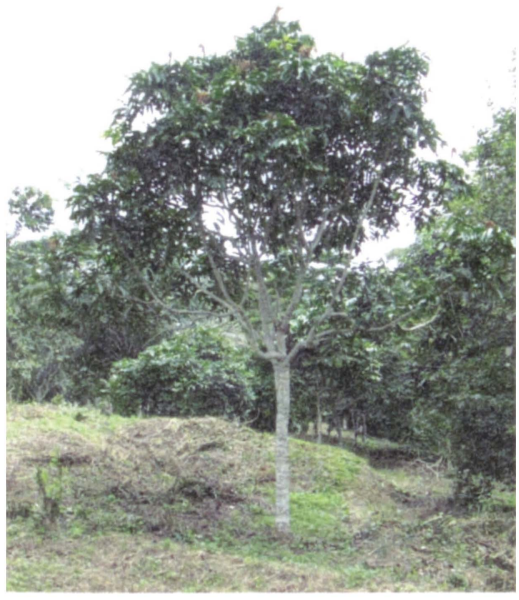

Tree of seed origin

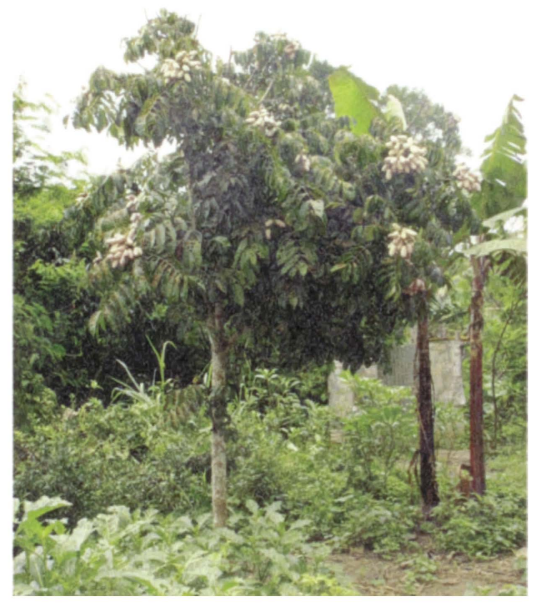

Tree of cutting origin

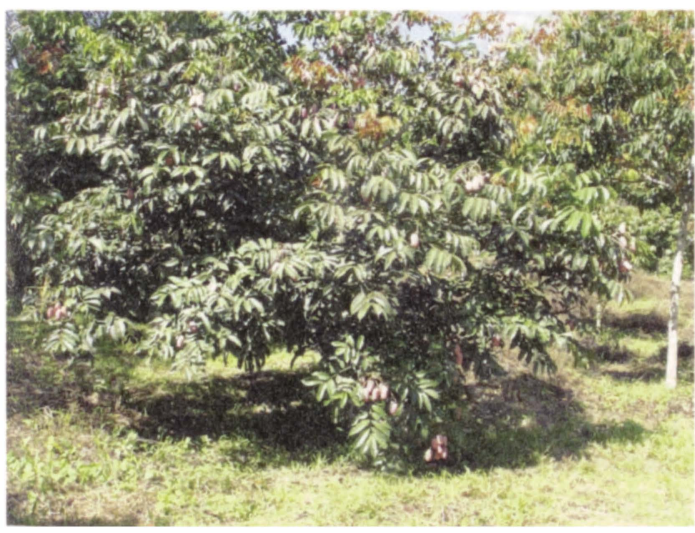

Tree of marcot origin
Figure 1. Typical D. edulis trees of seed, cutting and marcot origin in Cameroon 
In addition, the authors are not aware of any published studies that have rigorously quantified the effect of propagation methods on the above ground growth attributes of any indigenous fruit tree under domestication in Africa, beyond those that looked at their fruiting characteristics.

Of late, carbon sequestration has become a 'hot' issue. Trees generally store carbon (C) in above and below ground parts (stems, branches and roots. Most tree products (fruits, nuts, vegetables, spices, bark, oils, resin, etc.) for which the trees are grown, can be harvested with negligible impact on overall $\mathrm{C}$ stock of the production system. Trees in agricultural systems constitute major potential $\mathrm{C}$ sinks capable of absorbing and storing large quantities of atmospheric $\mathrm{C}$ in live biomass. If trees are integrated into agricultural systems and judiciously managed together with crops and/or animals $\mathrm{C}$ sequestration can even be improved over current figures (Albrecht and Kandji, 2003; Nair et al., 2009; Soto-Pinto et al., 2010; Takimoto et al., 2008). It is in this vein that agroforestry was recently recognized as a greenhouse gas mitigation strategy under the Kyoto Protocol for biological C sequestration (Nair et al., 2009). Watson et al. (2000) reported that $\mathrm{C}$ sequestration rates ranging from 1.5 to $3.5 \mathrm{Mg} \mathrm{C} \mathrm{ha}^{-1} \mathrm{y}^{-1}$ and a tripling of $\mathrm{C}$ stocks in a 20-year period, to $70 \mathrm{MgC} \mathrm{ha}^{-1} \mathrm{y}^{-1}$ was achievable in mature agroforestry systems. Albrecht and Kandji (2003) maintain that the $C$ sequestration potential in agroforestry systems could range between 29 and $53 \mathrm{Mg} \mathrm{ha}^{-1} \mathrm{y}^{-1}$ in the humid tropics of Africa.

However, agroforestry which provides a dual function of strengthening food security and $\mathrm{C}$ sequestration to fight climate change is still not well-understood. Consequently, it was necessary to initiate this study in order to gain a better insight into the effect of propagation methods - used in the clonal propagation of fruits trees - on their above ground growth attributes. Knowledge of the above ground growth attributes of individual trees is a vital part of the effort to design and manage agroforestry systems and their inherent agro-ecosystems services. In addition, selecting and domesticating fruit trees that display high carbon sinks, would provide the necessary arguments to promote tree crop cultivation, as farmers would not only gain from the tree products, but could also gain extra revenue from the $C$ stock in their trees offered by various environmental service reward mechanisms.

Diversification of the 'mother' clonal production population is crucial in developing a successful domestication process for pest/disease risk aversion and/or to avoid poor performance of individual trees as a result of inbreeding depression. Through agroforestry, risk aversion can also be achieved by diversification of the agro-ecosystems through the introduction of alternative tree species and food crops in ways that would provide food, income and other agro-ecological system functions (nutrient recycling, erosion control, habitat for flora and fauna, carbon sequestration, etc.) (Leakey, 1999; 2010).

Within the last decade, Allanblackia has become a subject of international interest to Unilever and other commercial enterprises as the seeds contain a unique edible oil that can be used to develop healthy food products, more specifically, healthy spreads that are low in trans-fats (Ochieng, 2007). Unilever estimates that the potential market for Allanblackia oil is more than 100,000 tons annually, provided the right quality standards are met. 


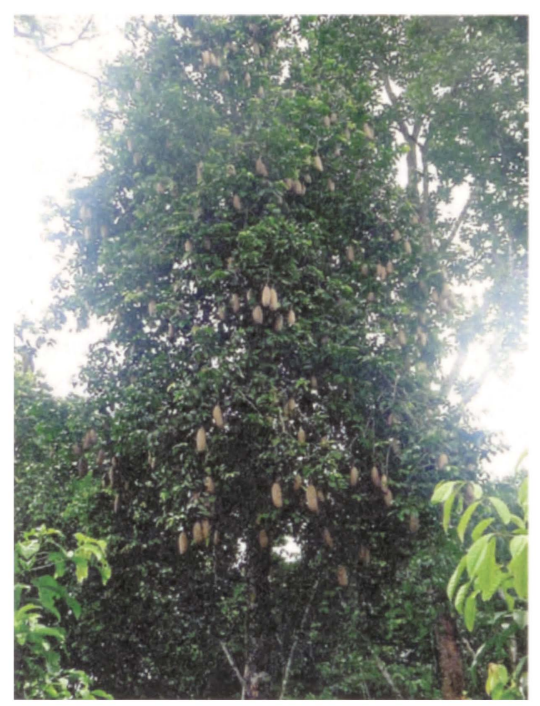

Figure 2: Typical Allanblackia floribunda tree in the humid forest of Cameroon

In addition to a very slow germination rate of less than $5 \%$, A. floribunda has a long juvenile phase to fruiting of at least 12 years (Vivien and Faure, 1996). Recently, however, new techniques developed in Ghana and Tanzania on A. parviflora and A. stuhlmannii respectively, have greatly improved the nursery germination success rate (Ofori et al., 20II).

Allanblackia is an allogamous and dioecious species. Thus, vegetative propagation techniques are needed to capture certain desirable fruit or tree traits so as to produce planting materials that have the same genetic characteristics as the mother trees. Recent studies by Atangana et al. (2006) on A. floribunda leafy stem cuttings recorded $68.7 \%$ rooting success at 25 weeks after setting up the experiment with cuttings obtained from juvenile shoots of a coppiced $A$. floribunda tree. These figures did not change till the end of the experiment at 38 weeks. Though successful, this approach to vegetative propagation is slow, and only a few roots are produced per cutting.

On farm cultivation of Allanblackia spp. is therefore constrained by propagation success (both through sexual and vegetative propagation techniques) (Munjuga et al., 2008). According to Bhojwani and Razdan (1996), a shift from sexual to clonal reproduction allows for the faithful reproduction of individuals with superior features (traits) by eliminating the uncertainty in the transmission of favoured traits over reproductive cycles which is associated with sexual reproduction. Vegetative propagation (grafting, budding and marcotting) has also been used to achieve early fruiting and tree dwarfing (Akinnifesi et al., 2008; 2009). For example, grafted Uapaca kirkiana began to produce fruits after only 2-3 years, while those derived from seedlings took 12-15 years before fruiting (Akinnifesi et al., 2008; 2009). Moreover, dwarfing produces trees that are smaller at harvest, thus facilitating fruit collection. 


\section{Objectives}

The main objectives of this research were to assess: (i) below ground and above ground growth attributes of fruiting D. edulis trees of seed and vegetative origins (cuttings and marcots), and (ii) the amenability of vegetative propagation techniques (grafting) in the reduction of the long juvenile phase to first fruiting in A. floribunda.

\section{Summary of research methods}

The study on below ground growth attributes was conducted in D. edulis orchards established in 1999 and 2001, respectively, by the World Agroforestry Centre (ICRAF) in the equatorial humid forest zone of Cameroon. This orchard is situated near Mbalmayo ( $3040^{\prime} \mathrm{N}, 1 \mathrm{I}^{\circ} \mathrm{O0} \mathrm{E}$ ) at $650 \mathrm{~m}$ above sea level, with $\mathrm{I}, 500$ hours/annum of insolation, and a bimodally distributed total annual rainfall of $1,200-2,500 \mathrm{~mm}$.

The orchard was originally set up as a comparative growth trial between D. edulis trees of seed and vegetative (juvenile cuttings and marcots) origin from the same mother plants that had at most three months difference in age. The trial was established as a randomized complete block design of Io replicates each laid out as single tree plots. Trees were transplanted at a spacing of roxio $\mathrm{m}^{2}$. Tree density per hectare is thus 100 . The soils of Mbalmayo fall under the ferrasol major soil grouping with soil unit defined as a xanthic ferrasol (FAO, 199I). Weeds were manually controlled in the plots using cutlasses.

Below ground root systems of D. edulis trees of seed and vegetative origins were totally excavated and structural root morphology described and quantified for each tree type. Similarly, fine root ( $\mathrm{d} \leq 2 \mathrm{~mm}$ ) distribution patterns of $\mathrm{D}$. edulis tree types (seed, cutting and marcotting origins) based on root density (RD), root length density (RLD) and root weight density (RWD) were assessed in soil profiles dug adjacent each tree type of D. edulis. In a separate study, above ground growth attributes (tree height, crown spread, diameter at breast height, and shoot density per tree type) of ro year old trees of D. edulis of seed and vegetative (cutting and marcot) origins were also assessed. In addition, a nondestructive method was used in assessing the above ground biomass of $D$. edulis trees of seed and vegetative origin. This data was subsequently computed into allometric regression models developed by Chave et al. (2005) to estimate above ground biomass. Similarly, below ground biomass was estimated using regression models developed by Cairns et al. (1997), which can predict root biomass based on above ground measurement data. Carbon stocks in the biomass were estimated in line with IIPC 2006 guidelines.

The amenability of A. floribunda to grafting was assessed by grafting scions from fruiting female trees onto eighteen month old rootstocks using side tongue, top cleft, side veneer, and whip-and-tongue methods under nursery conditions. In parallel, side tongue and inverted ' $T$ ' budding methods were also tested in situ on young A. floribunda wildings growing under semi-deciduous and evergreen tree covers. In addition, the effects of protecting side tongue grafts with non-perforated, translucent plastic, perforated translucent plastic and aluminium foil were assessed.

All data were subjected to statistical analysis and unless otherwise stated, statistical significance is given at the $5 \%$ level. 


\section{Summary of results}

The results of our investigations on $\mathrm{D}$. edulis indicate that trees of seed origin were characterized by a tap root, reaching depths of about $1.20 \mathrm{~m}$, whereas trees of cutting origin showed three strong vertical roots $(d>5 \mathrm{~mm})$ with the longest reaching depths of $1.31 \mathrm{~m}$ Similarly, trees of marcot origin were observed to have thick, relatively short prominent vertical roots, reaching depths of $1.15 \mathrm{~m}$ (Asaah et al., 2010) (Fig. 3).

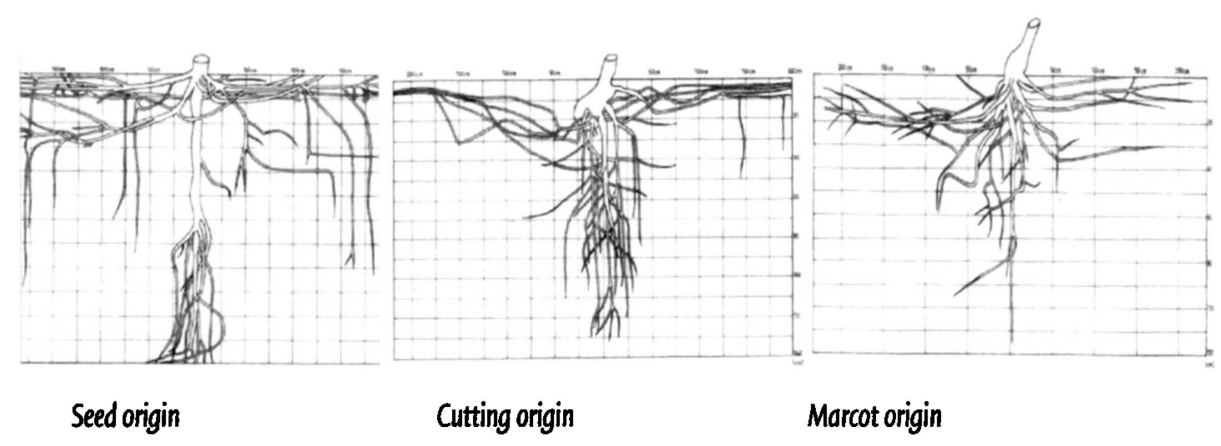

Figure 3: Root morphology of 5 years old D. edulis trees of seed, cutting and vegetative origins, Cameroon

In addition, trees of seed origin had greater fine root density $(R D)(P \leq 0.00 r)$ than trees of vegetative origin (cuttings and marcots) in the upper soil stratum $(0-30 \mathrm{~cm})$. Trees of seed origin were also shown to have an exponential distribution pattern for fine root density and root length within depth to $80 \mathrm{~cm}$. In contrast, the distribution patterns of fine roots of trees of vegetative origin (cuttings and marcots) were quadratic for the same variables which increased in the $20-30 \mathrm{~cm}$ soil depth stratum before declining steadily to a depth of $80 \mathrm{~cm}$ (Asaah et al., in press). Furthermore, shoot density, defined as number of shoots per tree, and height differed significantly ( $p=0.004$ and $p=0.005$, respectively) amongst tree origins. Trees of seed and cutting origins had single-stem shoots whereas marcots had 6 shoots per tree on average. Trees of cutting origin grew tallest, with a mean height of $8.4 \pm 2.2 \mathrm{~m}$ compared to $6.7 \pm 0.9 \mathrm{~m}$ and $7.6 \pm 1.9 \mathrm{~m}$ for trees of marcot or seed origins, respectively. Mean carbon (C) sequestration estimated using allometric models differed significantly $(\mathrm{p}=0.014)$ between trees of vegetative origin and those of seed origin, with to years old $D$. edulis trees of cutting and marcot origins sequestrating averagely $26.8 \pm 19.1 \mathrm{Mg} \mathrm{C}^{-1}$ and $21.74 \pm 12.8 \mathrm{Mg} \mathrm{C}^{-1} \mathrm{ha}^{-1}$ respectively over ro years, compared to $13.10 \pm 9.4 \mathrm{Mg} \mathrm{C} \mathrm{ha}^{-1}$ for trees of seed origin (Asaah, 2012) (Figs. 4 and 5). 


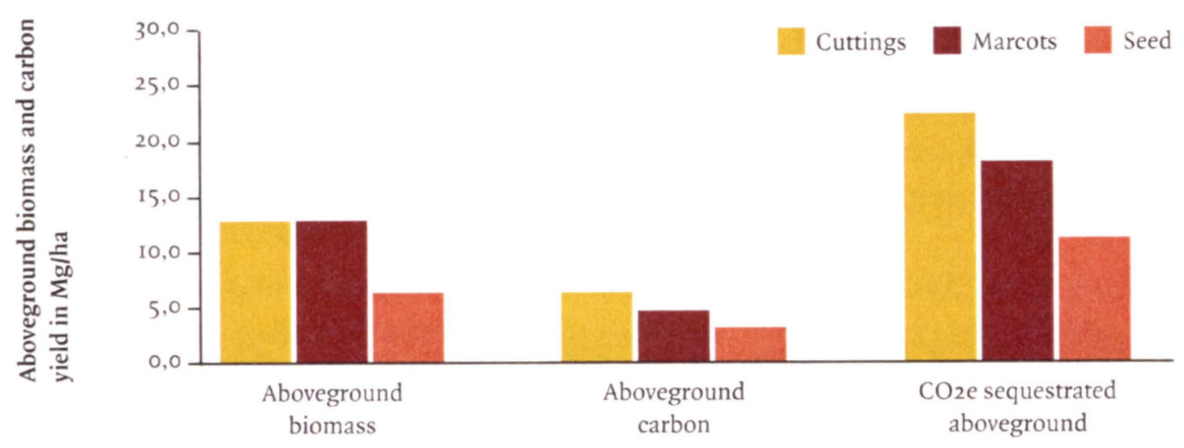

Figure 4: Biomass, carbon and $\mathrm{CO}_{2 e}$ sequestrated aboveground in 10 years old D. edulis trees of seed and vegetative origins (mean \pm s.e.d $\mathrm{Mgha}^{-1}$ )

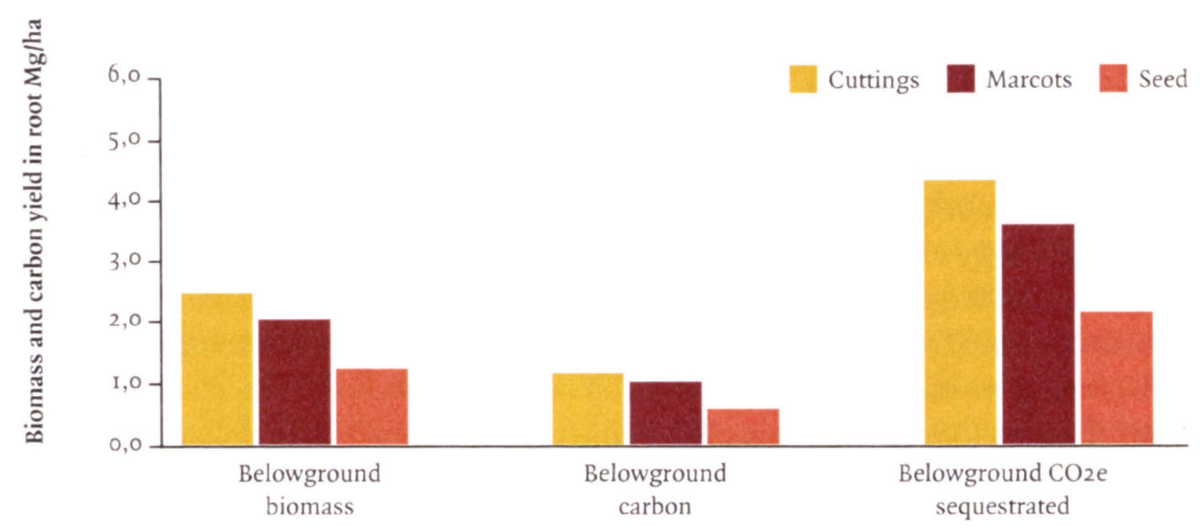

Figure 5: Biomass, carbon and $\mathrm{CO}_{2 e}$ sequestrated belowground in 10 years old D. edulis trees of seed and vegetative origins $\left(\right.$ mean \pm s.e.d $\left.M g h a^{-1}\right)$

In summary, the results from the studies on D. edulis suggest that vegetative propagation of the species, besides reducing the long juvenile phase to fruiting and maintaining trueness in the transfer of desirable traits over generations, also results in trees that are apparently less competitive for below ground resources. In addition, vegetative propagated trees of $D$. edulis were shown to have an apparently stable root system with trees bigger in stature and higher in carbon sinks than trees of seed origin.

Concomitantly, A. floribunda scions were taken from female trees, and grafted onto rootstocks using side tongue, top cleft, side veneer, and whip-and-tongue methods under nursery conditions. In a separate experiment, side tongue and inverted ' $T$ ' budding methods were also tested in situ on young A. floribunda wildings growing under semi- 
deciduous and evergreen tree covers. In addition, the effects of protecting side tongue grafts with non-perforated, translucent plastic, perforated translucent plastic and aluminium foil were assessed. A. floribunda was shown to be amenable to grafting both under nursery and field (in situ) conditions. Under nursery conditions, side tongue grafts were significantly more successful $(80.0 \pm 6.3 \%)$, than grafts of side veneer $(52.5 \pm 7.9 \%)$, top cleft $(55.0 \pm 7.9 \%)$ and whip-and-tongue $(50.0 \pm 7.9 \%)$. The success of side tongue grafts was further increased $(86.7 \pm 6.2 \%)$ under evergreen shade when grafts were protected by non-perforated translucent plastic (Asaah et al., 20ri). A grafted A. floribunda tree transplanted in the field in 2007 flowered and carried a single fruit to maturity after 4 years, thereby reducing the long juvenile period to first fruit production of about I0-I2 years (Vivien and Faure, 1996) to less than 5 years (Asaah, 2012) (Fig. 6).

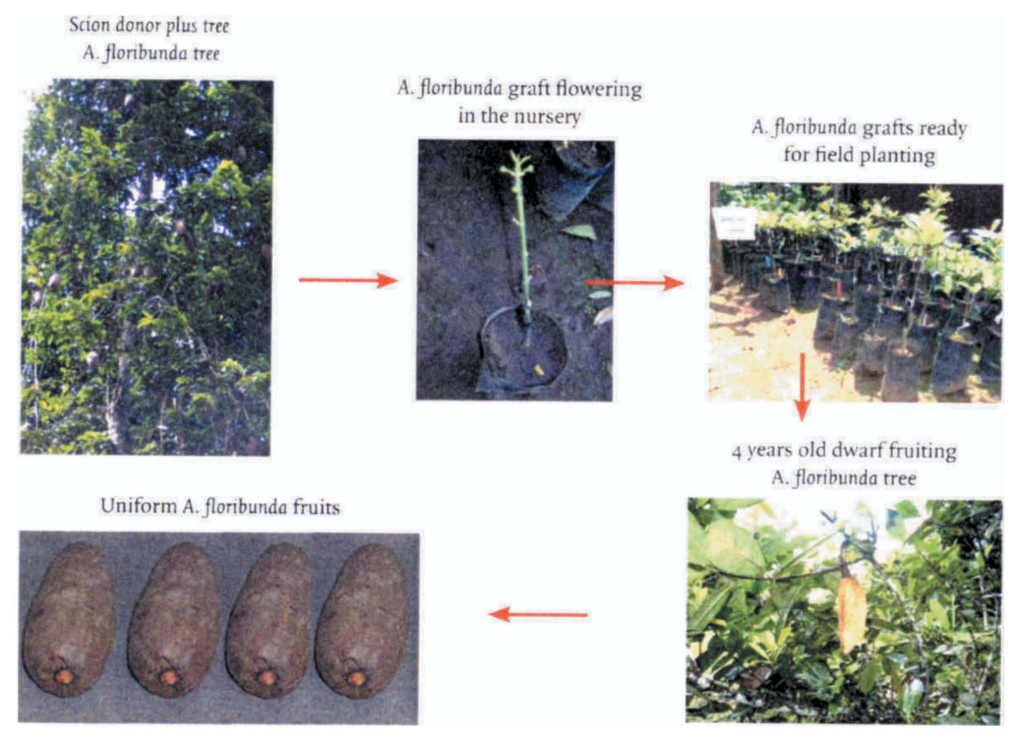

Figure 6: Juvenile phase to fruiting in A. floribunda shortened to 4 years via grafting, Cameroon 


\section{Conclusion}

To the best of our knowledge, the effect of propagation methods on the below ground and above ground growth attributes and their $\mathrm{C}$ storage potential examined in the present study on D. edulis, has not previously been the subject of research and publication. Similarly, the reduced juvenile period to first fruit production to less than 5 years in A. floribunda grafts reported in this research is apparently the first evidence of this sort published on the species. The findings of this research are therefore pertinent to efforts towards indigenous fruit/nut tree domestication. However, the research should be considered as a pilot study aimed at obtaining insights into the effect of vegetative propagation methods on the above and below ground growth and development of improved planting materials of $D$. edulis and $A$. floribunda under domestication. Further research on these species should focus on water use efficiency and fruit production in trees of seed and vegetative origins. In addition, species-specific allometric regression model(s) should be developed to assess carbon stock in trees of seed and vegetative origins with more precision.

\section{Acknowledgement}

The authors are grateful to the International Fund for Agricultural Development (IFAD), Belgian Development Cooperation, Unilever and World Agroforestry Centre that sponsored the field research, and VIIR-UOS scholarship and Short Research Stay (SRS) scholarship programme of Ghent University.

\section{References}

Akinnifesi, F.K., Mng'omba, S.A., Sileshi, G., Chilanga, T.G., Mhango, J., Ajayi, O.C., Chakeredza, S., Nyoka, B.I., Gondwe, F.M.T. (2009). Propagule type affects growth and fruiting of Uapac.a kirkiana, a priority indigenous fruit tree of southern Africa. Hortscience, 44(6): $662-1667$.

Akinnifesi, F.K., Kang, B.T., Ladipo, D.O. (1999). Structural root form and fine root distribution of some woody species evaluated for agroforestry systems. Agroforest Syst 42:121-138.

Akinnifesi, F.K., Kang, B.T., Tijani-Eniola, H. (1995). Root size distribution of Leucaena leucocephala hedgerows as affected by pruning and alley cropping. Nitrogen Fixing Trees Research Report 13:63-69.

Akinnifesi, F.K., Rowe, E.C., Livesley, S.J., Kwesiga, F., Vanlauwe, B., Alegre, J. (2004). Tree Root Architecture. In: Chin Ong, Meine van Noordwijk, Georg Cadisch (eds) Belowground Interactions in Tropical Agroecosystems: Concepts and models with Multiple Plant Components, Wallingford, UK: CAB Publishing, pp 6r-8I.

Akinnifesi, F.K., Sileshi, G., Mkonda, A., Ajayi, O.C., Mhango, J., Chilanga, T. (2008). Germplasm supply, propagation and nursery management of miombo fruit trees. In: Akinnifesi, F.K., Leakey, R.R.B., Ajayi, O.C., Sileshi, G., Tchoundjeu, Z., Matakala, P., Kwesiga, F.R. (eds) Indigenous Fruit Trees in the Tropics: Domestication, Utilization and Commercialization. CABI Publishing, Wallingford, UK, pp 34I-368.

Albrecht, A., Kandji, S.T. (2003). Carbon sequestration in tropical agroforestry systems. Agriculture, Ecosystem and Environment, 99:15-27.

Anderson, J.M.,.Ingram, J.S. (1993). Tropical Soil Biology and Fertility: a handbook of methods (2nd edition). $\mathrm{CAB}$ International, Wallingford, UK.

Asaah, E.K., Wanduku, T.N., Tchoundjeu, Z., Kouodiekong, L., Van Damme, P. (In press). Do propagation methods affect the fine root architecture of African Plum (Dacryodes edulis (G. Don H. J. Lam)? Trees Structure and Function o0:00-00. 
Asaah, E.K., Tchoundjeu, Z., Ngahane, W., Tsobeng, A., Kouodiekong, L., Jamnadass, R., Simons, A. (20II). Allanblackia floribunda - a new oil tree crop for Africa: amenability to grafting New Forest. 41:389398. DOI: 10.1007/srio56-010-9230-z.

Asaah, E.K., Tchoundjeu, Z., Wanduku, T.N., Van Damme, P. (2010). Understanding structural roots system of 5-year-old African plum tree (D. edulis) of seed and vegetative origins (G. Don) H. J. Lam). Trees Structure and Function. 24:789-796, DOI: 10.1007/s00468-010-0449-2.

Asaah, E.K. (2012). Beyond vegetative propagation of indigenous fruit trees: case of Dacryodes edulis (G.Don) H. J. Lam and Allanblackia floribunda Oliv. PhD. thesis. Faculty of Bioscience Engineering, Ghent University, Belgium 23I pp. ISBN-number: 978-90-5989-500-3.

http://www.tropicallab.ugent.be/thesisebenezar.pdf.

Atangana, A.R., Tchoundjeu, Z., Asaah, E.K., Simons, A.J., Khasa, D.P. (2006). Domestication of Allanblackia floribunda: Amenability to vegetative propagation. Forest Ecol Manag, 237:246-251.

Bayala, J., Teklehaimanot, Z., Ouedraogo, S.J. (2004). Fine root distribution of pruned trees and associated crops in a parkland system in the Burkina Faso. Agroforestry Systems, 60:13-26.

Bhojwani, S.S., Razdan, M.K. (1996). Plant tissue culture: Theory and practice. Elsevier, Amsterdam, Netherlands.

Cairns, M.A., Brown, S., Helmr, E.H., Baumgardner, G.A. (1997). Root biomass allocation in the world's upland forests. Oecologia, III:I-II.

Chaturvedi, O.P., Das, D.K. (2003). Studies on the rooting pattern of 5 -year-old important agroforestry tree species grown in the North Bihar, India. Forest, Trees and People 40: 89-100.

Chave, J., Andalo, C., Brown, S., Cairns, M.A., Chambers, J.Q., Eamus, D., Fölster, H., Fromard, F., Higuchi, N., Kira, T., Lescure, J.P., Nelson, B.W., Ogawa, H., Puig, H., Riéra, B., Yamakura, T. (2005). Tree allometry and improved estimation of carbon stocks and balance in tropical forests. Oecologia, 145:87-99.

Coutts, M.P. (1983). Root architecture and tree stability. Plant Soil, 71:171-188.

FAO (199r). Digitized soil map of the world. vol I Africa. Release 1.0 - November 199I. World soil resources report $67 / 1$. FAO, Land and Water Development Division, Rome, Italy.

Huxley, P.A. (1983). Some characteristics of trees to be considered in agroforestry. In: Huxley, P. A. (Ed), Plant Research and Agroforestry, pp 3-12.ICRAF, Nairobi, Kenya.

IPCC (2006). Guidelines for national greenhouse gas inventories - volume 4: Agriculture, land use and forestry (GL-AFOLU). http://www.ipcc-nggip.iges.or.jp.

Leakey, R.R.B. (1999). Agroforestry for biodiversity in farming systems. In: Collins WW and Qualset CO (eds) Biodiversity in Agroecosystems. CRC Press, Boca Raton, USA) pp 127-146.

- (2010). Agroforestry: a delivery mechanism for Multi-functional Agriculture. In: Handbook on Agroforestry: Management Practices and Environmental Impact, 46I-47I, Ed. Lawrence, R. Kellimore, Nova Science Publishers. Environmental Science, Engineering and Technology Series, USA.

Munjuga, M., Ofori, D., Sawe, C., Asaah, E., Anegbeh, P., Peprah, T., Mpanda, M., Mwaura L., Mtui, E., Sirito, C., Atangana, A., Henneh, S., Tchoundjeu, Z., Jamnadass, R, Simons, A.J. (2008).

Allanblackia propagation protocol. World Agroforestry Centre (ICRAF), Nairobi, Kenya, ISBN 978-929059-23I-0.

Nair, P.K.R., Kumar, B.M., Nair ,V.D. (2009). Agroforestry as a strategy for carbon sequestration. Journal of Plant Nutrition and Soil Science, 172:10- 23 doi: 10.1002/jpln.200800030.

Ochieng, C.M.O. (2007). Revitalising African agriculture through innovative business models and organisational arrangements: promising developments in the traditional crops sector. Journal of Modern African Studies, 45: $143-169$.

Odhiambo, H.O., Ong, C.K., Wilson, J., Deans, J.D., Khan A.A.H., and Sprent J.I. (200I). Root, soil, water and crop yield: tree crop interactions in semi-arid agroforestry system in Kenya. Plant and soil, 235: 221233. 
Ofori, D.O., Peprah, A.T., Cobbinah, J.R, Atchwerebour, H.A., Osabutey, F., Tchoundjeu, Z., Simons, A.J. , Jamnadass, R. (2011). Germination requirements of Allanblackia parviflora seeds and early growth of seedlings. New Forest, 41:337-348 DOI: ro.roo7/srro56-011-9252-I.

Schroth, G. (1995). Tree root characteristics as criteria for species selection and systems design in agroforestry. Agroforest Syst., 30:125 - 143.

- (1998). A review of belowground interactions in agroforestry- focusing on mechanisms and management options. Agroforest Syst., 43: 5-34.

Simons, A.J., Leakey, R.R.B. (2004). Tree domestication in tropical agroforestry. Agroforestry Systems 61:167$18 \mathrm{I}$.

Soto-Pinto, L., Anuzueto, M., Mendoza, J., Ferrer, J.G., de jong, Ben (2010). Carbon sequestration through agroforestry in indigenous communities of Chiapas, Mexico. Agroforestry Systems, 78:39-5I.

Takimoto, A, Nair, P.K.R., Alavalapati, J.R.R. (2008). Socioeconomic potential of carbon sequestration through agroforestry in the West African Sahel. Mit. Adapt. Strat. Global Change, 13:745-76r. doi: 10.10071 sIr027-007-9140-3.

Toky, O.P., Kuma, P., Khosla, P.K. (1989). Structure and function of traditional agroforestry systems in the Western Himalaya. Biomass and Productivity. Agroforestry System 9:47-70.

van Noordwijk, M., Purnomosidhi, P. (1995). Root architecture in relation to tree-soil-crop interactions and shoot pruning in agroforestry. Agroforestry Systems 30: 161-173.

Vanlauwe, B:, Aihou, K., Aman, S., Tossah, B.K., Diel, J., Lyasse, O., Hauser, S., Sanginga, N., Merckx, R. (2002). Maize N and P uptake as affected by particulate organic matter and soil characteristics for soil from the West-African moist savanna zone. Biol Fert Soils, 30: 440-449.

Vivien, J., Faure, J.J. (1996). Fruitiers sauvages d'Afrique (espèces du Cameroun). Paris, France, CTA. 416 p.

Vogt, K.A., Persson, H. (199I). Measuring growth and development of roots. In: Lassoie J.P. and Hinckley T.M. (eds) Techniques and Approaches in the Forest Tree Ecophsiology. CRC Press, Boca Raton, FL, USA. pp 477-501.

Von Maydell, H.J. (1987). Agroforestry in the dry zone of Africa: past, present and future. In: Steppler, H.A., Nair, P.K.R., (Eds) Agroforestry: A Decade of development, pp 89-II6. ICRAF, Nairobi, Kenya.

Watson, R.T., Noble, I.R., Bolin, B., Ravindranath, N.H., Verardo, D.J., Dokken, D.J. (200o). Land Use, Land-Use Change, and Forestry. Intergovernmental Panel on Climate Change (IPCC), Special Report. Cambridge Univ. Press., New York. 